\title{
Polyculture of Litopenaeus vannamei shrimp and Mugil platanus mullet in earthen ponds
}

\author{
Léa Carolina de Oliveira Costa ${ }^{1}$, João Antônio Amaral Xavier ${ }^{1}$, Luis Fernando de Matos Neves ${ }^{2}$ \\ Ana Maria Volkmer de Azambuja ${ }^{3}$, Wilson Wasielesky Junior ${ }^{1}$, Mario Roberto Chim Figueiredo ${ }^{1}$ \\ ${ }^{1}$ Programa de Pós-Graduação em Aquicultura, Instituto de Oceanografia, FURG (Mestrado). \\ ${ }^{2}$ Instituto de Ciências Biológicas, FURG. \\ ${ }^{3}$ Instituto de Matemática, Estatística e Física - IMEF - FURG.
}

\begin{abstract}
The objective of the present study was to evaluate the growth performance of the shrimp Litopenaeus vannamei and the mullet Mugil platanus in earthen ponds $\left(200 \mathrm{~m}^{2}\right)$ located in the Laboratory of Continental Aquaculture of Universidade Federal do Rio Grande (FURG), in both polyculture and monoculture systems. The study consisted of three replicates, as follows: shrimp monoculture (SM), shrimp and mullet polyculture (PO) and mullet monoculture (MM). The stocking density was 10 post-larvae shrimp (PL) $\mathrm{m}^{-2}$ and 0.67 mullet $\mathrm{m}^{-2}$. Fish and shrimp were fed commercial shrimp meal ( $38 \%$ crude protein) once a day. Initially, the amount of feed to shrimp was $20 \%$ of their total biomass which was later reduced to $5 \%$. Mullets were fed at $5 \%$ of their stocked biomass. The experiment lasted 79 days during the summer of 2007/2008. At harvest, shrimp in monoculture had weight gain (15.59 g), specific growth rate $\left(8.40 \%\right.$ day $\left.^{-1}\right)$, apparent feed conversion $(0.88)$, survival $(91 \%)$ and production $\left(1.454 \mathrm{~kg} \mathrm{ha}^{-1}\right)$ significantly higher than in polyculture $\left(1.039 \mathrm{~kg} \mathrm{ha}^{-1}\right)$. Mullets in polyculture had significantly better weight gain $(42.72 \mathrm{~g})$ and specific growth rate $\left(3.99 \%\right.$ day $\left.^{-1}\right)$ than those in monoculture $(31.04 \mathrm{~g}$ and $3.69 \%$ day $^{-1}$, respectively), while the mullet condition factor was significantly smaller in polyculture (1.06) than in monoculture (1.13). The apparent feed conversion of the mullets did not present significant differences between monoculture (2.50) and polyculture (2.40). The physical and chemical water parameters were not significantly different in any of the experiments, except for the transparency, which was higher in earthen ponds with mullet monoculture. Polyculture of shrimp and mullet reared together in earthen ponds negatively affects the shrimp production and favors the production of mullets.
\end{abstract}

Key Words: estuarine aquaculture, fertilization, multitrophic aquaculture, mugilidae

\section{Introduction}

Polyculture is an integrated production system in which two or more aquatic species are grown in the same place. This process is mainly utilized to increase production by using available ecological resources in a more efficient way (Silva et al., 2006), e.g., food sources and the culture area. Moreover, this system optimizes the use of facilities and labor, increasing its environmental and economic sustainability. The polyculture system is highly productive and can be very lucrative, with a low environmental impact (Valenti, 2002). According to Vinatea (1999), polyculture is more desirable and, as suggested by Naylor et al. (2000), it is important to give priority to the use of native species.

In this culture system, the use of species that occupy inferior trophic levels (herbivores and omnivores) is taken into account. The easy adaptation of these species to feeding (natural or artificial food) can reduce the risk of pollution of natural water bodies (Vinatea, 1999). In many cases, one species improves the food availability for another species, which thus increases the overall production of the culture system. However, earthen ponds used for polyculture are complex and still poorly understood (Rahman et al., 2008).

In Brazil, there are few studies about polyculture focusing on sea and estuarine species (Córdoba \& Messina, 2005). A potential species for this type of culture is the mullet Mugil platanus. Due to its biological characteristics, it can be a new alternative for aquaculture in tropical and tempered regions (Poersch et al., 2007). In South America, Mugil platanus can be found throughout the coast, from Rio de Janeiro, in Brazil, as far as Argentina (Menezes \& Figueiredo, 1985). Mugil platanus is an euryhaline species (Godinho, 2005) that can endure confined conditions and easily accepts artificial food (Fonseca Neto \& Spach, 1998/ 1999; Sampaio et al., 2001).

A great advantage in rearing exotic species is the existence of a technological package that contributes to the development of the local aquaculture. This possibility 
became available when the shrimp Litopenaeus vannamei was introduced into Brazil in the 1980s and became commercially viable (Rodrigues, 2001).

The Pacific white shrimp Litopenaeus vannamei (Boone, 1931) accounts for about $70 \%$ of all the penaeid shrimp cultured worldwide (Lin \& Chen, 2003; FAO, 2010). It is the most predominant shrimp species the in Brazilian mariculture.

The objective of the present work was to evaluate the polyculture of shrimp Litopenaeus vannamei and the mullet Mugil platanus in earthen ponds supplied with brackish water.

\section{Material and Methods}

The experiment was conducted at the Aquaculture Continental Laboratory (LAC) of Universidade Federal do Rio Grande (FURG), located at Saco do Justino (32 $01^{\circ} 40^{\prime \prime} \mathrm{S}$ $52^{\circ} 05^{\prime} 40^{\prime \prime} \mathrm{W}$ ) in an inlet in the Patos Lagoon. The experiment lasted 79 days, from December 05, 2007 to February 22, 2008.

Nine earthen ponds of $200 \mathrm{~m}^{2}$ each were used. Prior to the trial, lime was applied to the ponds at 300 g. $\mathrm{m}^{-2} \mathrm{CaO}$. Subsequently, the earthen ponds were supplied with water pumped from Patos Lagoon estuary, Southern, keeping the water column at $80 \mathrm{~cm}$. Screens (mesh $<900 \mathrm{~nm}$ ) were used at the water pumping site as a filter to prevent the entry of undesirable organisms. Water was added or removed only to replace the amount lost by evaporation and/or infiltration. After $\mathrm{pH}$ stabilization, the ponds were fertilized using $75 \mathrm{~g} \mathrm{~m}^{-2}$ of tanned cow manure. During the experiment, pond fertilization $\left(75 \mathrm{~g} \mathrm{~m}^{-2}\right)$ was performed every 15 days or as indicated by the water transparency.

The experimental design was completely randomized with three treatments and three replicates: Treatment 1 $(\mathrm{SM})=$ shrimp monoculture, Treatment $2(\mathrm{PO})=$ shrimp and mullet polyculture and Treatment $3(\mathrm{MM})=$ mullet monoculture. The stocking density remained the same in the monoculture and polyculture experiments (10 shrimp $\mathrm{m}^{-2}$ and 0.67 mullet $\mathrm{m}^{-2}$ ).

The Litopenaeus vannamei post-larvae (PL) used in the study were produced with nauplii purchased from a commercial hatchery, Aquatec Industrial Pecuária Ltda, located in Rio Grande do Norte State, Brazil. At the Marine Aquaculture Station of Universidade Federal do Rio Grande (EMA-FURG), hatchery-produced post-larvae were kept at laboratory conditions until the PL 32 stage. Post-larvae were transported in oxygenated plastic bags to the LACFURG, where they were acclimated for a week in tanks of
$300 \mathrm{~L}$, with the same temperature and salinity as in ponds. Post-larvae were stocked in earthen ponds $\left(10 \mathrm{PL} \mathrm{m}^{-2}\right)$ at an initial weight of $0.02 \pm 0.003 \mathrm{~g}$.

Mullet Mugil platanus juveniles were caught in the Patos Lagoon estuary and stored in $300 \mathrm{~L}$ tanks until the beginning of the experiment. Mullets of $1.67 \pm 0.31 \mathrm{~g}$ were stocked at 0.67 mullets $\mathrm{m}^{-2}$ in the earthen ponds on the day of shrimp stocking.

Mullets and shrimp were fed a commercially available shrimp feed, (Guabi Active ${ }^{\circledR}$ ), with $38 \%$ crude protein. Feed was distributed in the ponds once a day, in the afternoon. Shrimp were fed according to the recommendations of Jory (2001). Mullets were fed 5\% of their total biomass throughout the entire culture period. To calculate the amount of feed, fish and shrimp morality was assumed to be $1 \%$ a week.

Sampling was performed at stocking and at 30,60 and at 79 days of culture; by 79 days, shrimp had reached commercial body weight. The weight and the length of the mullets and shrimp were also recorded. The following performance parameters were analyzed: weight gain (WG), survival (S), apparent feed conversion ratio (FCR), specific growth rate (SGR), condition factor $(\mathrm{CF})$ and yield (YIE). The formulas that were used are as follows:

$\mathrm{S}(\%)=($ final population/initial population $) \times 100$;

WG $(\mathrm{g})=$ final body weight - initial body weight;

$\mathrm{FCR}=$ total feed offered/animal weight gain;

SGR $\left(\%\right.$ day $\left.^{-1}\right)=[(\ln$ final body weight $-\ln$ initial body weight)/time of rearing (days) $] \times 100$;

$\mathrm{CF}=\left[\right.$ final weight $\left./(\text { total length })^{3}\right] \times 100$;

YIE $\left(\mathrm{kg} \mathrm{ha}^{-1}\right)=$ total harvested biomass/earthen pond area.

Water quality was recorded every morning. Dissolved oxygen $\left(\mathrm{DO}, \mathrm{mg} \mathrm{L}^{-1}\right)$ and temperature $\left({ }^{\circ} \mathrm{C}\right)$ were measured using a Solar ${ }^{\circledR}$ DO meter; salinity was measured using a Solar ${ }^{\circledR}$ manual refractometer $\left(\mathrm{g} \mathrm{L}^{-1}\right) ; \mathrm{pH}$ was measured using a Solar ${ }^{\circledR} \mathrm{pH}$ meter; and transparency was measured using a Secchi disk $(\mathrm{cm})$.

Statistical analysis was performed considering the two treatments (monoculture and polyculture) for both shrimp and mullets. To analyze animal growth over time, a twoway factorial ANOVA was performed considering rearing time and the treatments. To verify differences between treatments, Tukey's HSD test was used with a significance level of $5 \%$.

For the statistical analysis of WG, S\%, AFC, SGR, CF and YIE, Student's $t$-test was applied, with a significance level of $5 \%$. For the water quality parameters (dissolved 
oxygen, temperature, salinity, $\mathrm{pH}$ and transparency), a oneway ANOVA was performed, followed by Tukey's HSD test with a significance of $5 \%$.

\section{Results and Discussion}

Dissolved oxygen, water temperature, salinity and $\mathrm{pH}$ did not vary as a function of culture system $(\mathrm{P}>0.05$; Table 1). Salinity increased during rearing, but statistical differences between culture systems were not significant. Only water transparency (Table 1) in the mullet monoculture treatment was significantly higher $(\mathrm{P}<0.05)$ than in the shrimp monoculture and polyculture treatments. There was no significant difference $(\mathrm{P}>0.05)$ in water transparency between the shrimp monoculture and polyculture treatments.

Temperature, salinity and $\mathrm{pH}$ values were within the acceptable range for the culture of both species. Water transparency was higher in the mullet monoculture ponds, possibly because less feed was provided compared with other ponds. A smaller amount of feed offered translates into fewer nutrients for primary production. This may explain the greater transparency in the mullet monoculture ponds. Godinho (2005) argued that mullet ponds have transparencies between 10 and $110 \mathrm{~cm}$, so the values found in this work are within the acceptable range for rearing this species. On the other hand, dissolved oxygen apparently influenced neither growth nor survival of shrimp and mullet.

In the shrimp monoculture and polyculture earthen ponds, a higher amount of feed was offered than in the mullet monoculture ponds. Dissolved oxygen (DO) was expected to be higher in the mullet monoculture ponds. Phan-Van et al. (2008) compared the levels of DO in earthen tanks with and without tilapia Oreochromis niloticus and noted that the presence of fish led to an increase in the amount of DO, mainly in the water layers near the sediment. Fish activity promotes the diffusion of dissolved DO in the water column.

Table 1 - Means ( \pm standard deviation) of water quality parameters in the shrimp monoculture (SM), polyculture of mullet and shrimp (PO) and monoculture of mullet (MM) systems

\begin{tabular}{lccc}
\hline & SM & \multicolumn{1}{c}{ PO } & MM \\
\hline DO $\left(\mathrm{mg} \mathrm{L}^{-1}\right)$ & $5.56 \pm 2.43$ & $6.05 \pm 2.83$ & $6.70 \pm 2.26$ \\
Temperature $\left({ }^{\circ} \mathrm{C}\right)$ & $25.18 \pm 1.74$ & $25.42 \pm 1.71$ & $25.46 \pm 1.75$ \\
Salinity & $6.00 \pm 2.97$ & $5.79 \pm 2.97$ & $6.32 \pm 3.24$ \\
pH & $8.7 \pm 0.46$ & $8.46 \pm 0.70$ & $8.55 \pm 0.66$ \\
Transparency $(\mathrm{cm})$ & $64.37 \pm 20.92 \mathrm{~b}$ & $60.99 \pm 22.69 \mathrm{~b}$ & $74.19 \pm 12.07 \mathrm{a}$ \\
\hline
\end{tabular}

Means followed by the same letters in the same row indicate that the results do not differ significantly according to Tukey's HSD test $(\mathrm{P}>0.05)$.

DO - dissolved oxygen.
Wang et al. (1998) stated that the swimming of fish improves water management and the recycling of nutrients in ponds. The authors indicated the concentration of DO increased as fish density increased (up to $400 \mathrm{~kg}$ tilapia ha ${ }^{-1}$ ). They found lower DO levels in enclosures without tilapia. Comparing the average values of DO in polyculture $\left(6.05 \mathrm{mg} \mathrm{L}^{-1}\right)$ and in monoculture $\left(5.56 \mathrm{mg} \mathrm{L}^{-1}\right)$ of shrimp found in this study, in polyculture, the concentration of DO was slightly higher than in the shrimp monoculture.

The growth of mullets and shrimps, after 79 days (Table 2), varied significantly as a function of culture system $(\mathrm{P}<0.05)$. Shrimp exhibited higher body weights $(\mathrm{P}<0.05)$ in monoculture than polyculture $(15.58 \pm 3.10$ and $12.86 \pm 3.40 \mathrm{~g}$, respectively). On the other hand, mullets showed greater body weights $(\mathrm{P}<0.05)$ in polyculture than monoculture (47.02 \pm 31.17 and $34.08 \pm 15.12 \mathrm{~g}$, respectively).

Despite the beneficial effects observed in polyculture, the presence of mullets in the ponds stocked with shrimp may have deteriorated shrimp growth. This may have occurred due to the food competition between mullets and shrimps. Shrimp grew $18.8 \%$ more in the absence of mullets, while the mullets increased $27.3 \%$ more in polyculture than in monoculture. This result differs from the findings of Jana et al. (2007), in which the growth of freshwater prawn (Macrobrachium rosenbergii) and carp (Catla catla and Labeo rohit) was faster in polyculture than in monoculture. However, as opposed to the present study, Jana et al. (2007) fed the same amounts of feed in all of the treatments.

In this study, mullets were fed at $5 \%$ of their biomass throughout the culture period. Shrimp were initially fed at $20 \%$ of their biomass, and this level was reduced to $5 \%$ at the end of the culture. The smaller amount of feed provided for the mullets may have been decisive in the higher growth rates of mullets and the lower growth rates observed in shrimp in polyculture. The difference in mullet growth between the two systems suggests that for the mullets to achieve faster growth rates, they require feeding rates higher than $5 \%$. In the polyculture of $M$. platanus and

Table 2 - Mean weight (g) and standard deviation of shrimp and mullets during the experiment

\begin{tabular}{lcccc}
\hline \multirow{2}{*}{ Days } & \multicolumn{2}{c}{ Shrimp } & \multicolumn{2}{c}{ Mullets } \\
\cline { 2 - 5 } & Monoculture & Polyculture & Monoculture & Polyculture \\
\hline 0 & $0.02 \pm 0.003$ & $0.02 \pm 0.003$ & $1.68 \pm 0.30$ & $1.65 \pm 0.34$ \\
30 & $3.75 \pm 1.60 \mathrm{a}$ & $2.59 \pm 1.44 \mathrm{~b}$ & $14.65 \pm 9.83$ & $18.82 \pm 11.74$ \\
60 & $10.54 \pm 2.57 \mathrm{a}$ & $9.32 \pm 3.84 \mathrm{~b}$ & $26.05 \pm 10.65$ & $31.69 \pm 25.45$ \\
79 & $15.58 \pm 3.10 \mathrm{a}$ & $12.86 \pm 3.40 \mathrm{~b}$ & $34.08 \pm 15.12 \mathrm{~b}$ & $47.02 \pm 31.17 \mathrm{a}$ \\
\hline
\end{tabular}

Different letters in the same row, for both the columns of shrimp and mullets, indicate significant differences $(\mathrm{P}<0.05)$ according to Tukey's HSD test.

The rows without letters did not exhibit significant differences. 
L. vannamei, both species were in the same environment and had free access to the same feed. The mullet seemed to have a greater ability to capture the feed, which may explain their higher growth in monoculture. The same trend occurred in the culture of hybrid tilapia with Chinese shrimp Penaeus chinensis. Shrimp growth was hampered by the presence of fish in the same culture system (Wang et al., 1998). The authors suggested that tilapia were in competition for food with the shrimp. In this study, it can be inferred that mullets consumed a portion of the feed which was intended for shrimp.

Vieira \& Scaladrin (1991) claimed that young $M$. platanus are omnivores and ingest large volumes of sediment, which is supported by their botton-feeding habit preference. This relationship between mullet feeding habit and its diet matches that of L. vannamei, as suggested by Tian et al. (2001).

The performance of shrimp (Table 3) reared in polyculture versus monoculture differed significantly $(\mathrm{P}<0.05)$. The best results were found in the monoculture system. The average weight gain for shrimp reared in monoculture was $15.59 \mathrm{~g}, 18.8 \%$ higher than in polyculture $(12.65 \mathrm{~g})$. Shrimp specific growth rate was $8.4 \%$ and $8.1 \%$ day $^{-1}$ for mono- and polycultures, respectively. The apparent feed conversion was $0.88 \pm 0.19$ in monoculture and $1.18 \pm 0.57$ in polyculture. Shrimp survival rate was $91.59 \pm 4.27 \%$ in monoculture and $74.59 \pm 4.16 \%$ in polyculture. Shrimp yield was also $18.6 \%$ lower in polyculture than in monoculture.

The actual FCR in shrimp polyculture (1.18) is likely to be less than what calculations suggest, close to the FCR obtained in shrimp monoculture (0.88). The FCR achieved for mullet is probably greater than the calculated, since fish were more likely to ingest feed that was intended for shrimp. Carvalho (2008) found values of 0.39 and 0.42 for feed efficiency in mullets fed to satiation with diets of $35 \%$ and $40 \%$ crude protein, respectively. In this study, mullets were farmed under laboratory conditions for 35 days with high water exchange rates. In our study, since fish had no other food source than the feed provided, we can transform these FCR values to 2.56 and 2.38. These FCR values for mullets farmed alone (2.50) or in polyculture with shrimp (2.40) were close to those found by Carvalho (2008).

Jana et al. (2007) found FCR of 1.24 and 0.25 for Macrobrachium rosenbergii and carp (Catla catla and Labeo rohit) in monoculture, respectively. A FCR of 0.24 was observed when species were farmed in polyculture. If the growth performance of shrimp and mullet reared in polyculture in the present study were grouped, an average FCR value of 1.79 would be obtained. In the polyculture of M. rosenbergii with carp (C. catla and L. rohit), Houssain $\&$ Islam (2006) found FCRs ranging from 2.05 to 2.20, also by grouping the production of fish and shrimp together.

Ritvo et al. (1998) reared L. vannamei in tanks with dimensions of $30 \times 30 \times 60 \mathrm{~cm}$ with different substrates, stocking three shrimp in each tank. From days 1 to 80 , weight gain ranged from 13.75 to $16.04 \mathrm{~g}$, and FCR ranged from 1.39 to 1.62 , depending on treatments. In our study, we found very similar values for weight gain in the shrimp monoculture $(15.59 \mathrm{~g})$ and for the best FCR $(0.88)$.

For the mullets, most growth performance parameters were better in polyculture than monoculture. The average weight gain was $42.72 \mathrm{~g}$ and $31.04 \mathrm{~g}$ in polyculture and monoculture, respectively, which means a difference of $27.3 \%$. The specific growth rate was $3.69 \%$ day $^{-1}$ for monoculture and $3.99 \%$ day $^{-1}$ for polyculture. These two factors were significantly different $(\mathrm{P}<0.05)$ between the treatments (monoculture and polyculture).

The apparent FCR for mullets was 2.50 in monoculture and 2.40 in polyculture, so they were not statistically different $(\mathrm{P}>0.05)$. The condition factor was better $(\mathrm{P}<0.05)$ in monoculture (1.13) than in polyculture (1.06). The survival rates were very close in both treatments (81.96 and $83.91 \%$ in monoculture and polyculture, respectively). Survival was not significantly different $(\mathrm{P}>0.05)$. Mullet production was $34.3 \%$ higher in polyculture than in monoculture.

Polyculture experiments have been performed by placing one of the species in cages or enclosures within the ponds of the other species (Wang et al., 1998; Danaher et al., 2007) or in recirculation systems with more than one species

Table 3 - Performance parameters (mean \pm standard deviation) of shrimp and mullet reared in monoculture and polyculture after 79 days

\begin{tabular}{|c|c|c|c|c|c|c|}
\hline & \multicolumn{3}{|c|}{ Shrimp } & \multicolumn{3}{|c|}{ Mullets } \\
\hline & Monoculture & Polyculture & $\mathrm{P}$ & Monoculture & Polyculture & $\mathrm{P}$ \\
\hline Weight gain (g) & $15.59 \pm 0.75 \mathrm{a}$ & $12.65 \pm 1.74 b$ & 0.024 & $31.04 \pm 16.48 b$ & $42.72 \pm 12.23 \mathrm{a}$ & 0.036 \\
\hline Survival rate $(\%)$ & $91.59 \pm 4.27 \mathrm{a}$ & $74.59 \pm 4.16 b$ & 0.001 & $81.96 \pm 3.86 a$ & $83.91 \pm 2.37 \mathrm{a}$ & 0.036 \\
\hline Apparent feed conversion ratio & $0.88 \pm 0.19 \mathrm{a}$ & $1.18 \pm 0.57 b$ & 0.012 & $2.50 \pm 2.10 \mathrm{a}$ & $2.40 \pm 0.75 \mathrm{a}$ & 0.046 \\
\hline Specific growth rate $\left(\%\right.$ day $\left.^{-1}\right)$ & $8.40 \pm 025 \mathrm{a}$ & $8.14 \pm 0.35 b$ & 0.043 & $3.69 \pm 0.57 b$ & $3.99 \pm 0.75 \mathrm{a}$ & 0.032 \\
\hline Condition factor & - & - & & $1.13 \pm 0.06 \mathrm{a}$ & $1.06 \pm 0.08 \mathrm{~b}$ & 0.000 \\
\hline Production $\left(\mathrm{kg} \mathrm{ha}^{-1}\right)$ & $1454.98 \pm 127.33 \mathrm{a}$ & $1039.08 \pm 0.45 b$ & 0.001 & $207.76 \pm 96.64 a$ & $316.53 \pm 97.27 \mathrm{a}$ & 0.024 \\
\hline
\end{tabular}

Different letters in the same row for both the shrimp and mullet columns indicate a significant difference (P<0.05) between the results according to Student's t-test results. 
(Parsons et al., 2002; Henne et al., 2007). These procedures prevent competition for feed and provide other advantages for farming, including a better crop performance, without one species having a negative effect on the other (no interspecific competition).

The amount of feed consumed by shrimp in polyculture was probably not sufficient to provide an increased growth rate. Feed that was assumed to be eaten by the shrimp may have actually been consumed by mullets. Thus, FCR values for shrimp in polyculture may have been affected by this situation. Shrimp are bottom feeders and may consume their own wastes (Ritvo et al., 1998). Therefore, in the polyculture of L. vannamei with M. platanus, shrimp and mullets competed for space and food as they both prefer to feed on the bottom.

Oliveira \& Soares (1996) stated that, in their natural environment, mullets have a very large food spectrum, including cyanobacteria, algae, protozoa, metazoa and debris. Their diet composition varies with seasons. In their study they found 16 different food items in fish smaller than $30 \mathrm{~cm}$ in length. These authors also stated that mullets can be considered primary and secondary consumers, which demonstrates this diet adaptability.

Scorvo-Filho et al. (1995) found that the weight gain of mullets in monoculture was $69.6 \%$ higher at a fish stocking density of 0.16 fish $\mathrm{m}^{-2}$ than at $0.33 \mathrm{fish} \mathrm{m}^{-2}$. Thus, the highest fish stocking density of fish should result in lower amounts of food for each stocked organism. In this study, the weight gain of mullets was $27.3 \%$ higher in polyculture than in monoculture. Like in the present study, mullets were used at a density of $0.67 \mathrm{~m}^{-2}$, and a lower weight gain than that found by Scorvo-Filho et al. (1995) would be expected. However, the resulting weight gain in polyculture (42.72 g) was higher than that observed by these authors at a higher density ( $37.57 \mathrm{~g}$ with $0.33 \mathrm{fish} \mathrm{m}^{-2}$ ) but lower than that obtained for the lower density (53.96 g with $0.16 \mathrm{fish} \mathrm{m}^{-2}$ ).

When mullets and shrimp were reared together, the stocking density per $\mathrm{m}^{-2}$ increased in polyculture. However, competition for space and food was not the same between similar organisms (intra specific) as in the study by ScorvoFilho et al. (1995), but between crustaceans and fish (interspecific), with mullets benefiting shrimp.

Sampaio (2008) recorded a decrease in the condition factor of mullets with a drop in temperature. In their experiment, mullets had a condition factor of approximately 1.20 in the hottest period, which decreased to 0.90 in cooler periods. In this study, the condition factor was the only measurement of performance that was more improved in monoculture than in polyculture for mullets (1.13 and 1.06 , respectively). The values obtained in this study are close to those described by Sampaio (2008), although the temperature was not a limiting factor for growth.

The specific growth rates of shrimp in monoculture and polyculture were 8.40 and 8.14 , respectively. In a study by Houssain \& Islam (2006), the stocking density of $M$. rosenbergii varied in polyculture with carp. Shrimp were found to have specific growth rates from 3.99 to $4.2 \%$. Carvalho (2008) found 3.84 and $3.60 \%$ for the specific growth rate of mullets (M. platanus) fed diets containing $35 \%$ and $40 \%$ crude protein of animal origin over a 35-day rearing period under laboratory conditions. In the present study, in both the monoculture and polyculture of mullets, specific growth rates (3.69 and 3.99\%, respectively) for 79 days of rearing in earthen ponds were similar to those obtained by Carvalho (2008).

In the present study, shrimp survival rate was lower in polyculture than in monoculture, as shrimp was probably in disadvantage in terms of food competition with mullets, which may have also led to environmental stress, as reported by Uddin et al. (2007).

Muangkeow et al. (2007) evaluated the performance of $L$. vannamei in recirculating water systems for the rearing of shrimp and the tilapia $O$. niloticus. Animals were reared in different tanks and only the shrimp were fed. The authors did not report any difference in survival between treatments (ranging from $84.7 \%$ to $90.8 \%$ ). Uddin et al. (2006) observed greater survival for $M$. rosenbergii in monoculture than in polyculture with GIFT tilapia $(O$. niloticus). Candido et al. (2006) cultivated tilapia ( $O$. niloticus) in polyculture with $L$. vannamei for 120 days in freshwater and found a survival value between 83.33 and $100 \%$ for tilapia and between 83.3 and $86.1 \%$ for shrimp. In the present study, it was found that the survival rates for shrimp in monoculture and polyculture were 91.59 and $74.59 \%$, respectively, clearly showing a reduction in survival for shrimp in polyculture with mullets.

Carvalho (2008) found survival rates of 95.7 and $96.3 \%$ for $M$. platanus under laboratory conditions. Sampaio (2008) found survival rates of 97 and $98 \%$ for mullets in polyculture with sole (Paralichthys orbignyanus) in earthen ponds over a period of 192 days in autumn and winter. In the present work, the mullets achieved survival rates of 81.9 and $83.9 \%$ in monoculture and polyculture, respectively, which are slightly below the values previously cited.

Shrimp production in earthen ponds in monoculture and polyculture was 1454.98 and $1039.08 \mathrm{~kg} \mathrm{ha}^{-1}$, respectively. Mullet yield in monoculture was $207.76 \mathrm{~kg} \mathrm{ha}^{-1}$, and $316.53 \mathrm{~kg} \mathrm{ha}^{-1}$ in polyculture. Shrimp yield was higher in monoculture than polyculture. In contrast, yield for mullets was higher in polyculture than monoculture. 
When the production of the two species in polyculture was added up, yield (harvest) was $1,355.61 \mathrm{~kg} \mathrm{ha}^{-1}$. This yield is $8.8 \%$ lower than the shrimp yield in monoculture and $538.8 \%$ higher than the mullet yield in monoculture. Wang et al. (1998) reported 534.8 to $995.7 \mathrm{~kg} \mathrm{ha}^{-1}$ of yield in Chinese shrimp (Penaeus chinensis) in polyculture with tilapia for 93 days. However, the authors did not specify why the tilapia yield in polyculture was over $181.17 \mathrm{~kg} \mathrm{ha}^{-1}$, the highest yield reported in the literature. The difference is even greater $\left(459.28 \mathrm{~kg} \mathrm{ha}^{-1}\right)$ if shrimp yield in monoculture is taken into account.

The present study lasted sufficient time for the shrimp to reach a marketable size, considering that between the two farmed species, crustaceans have a shorter harvest period than mullets. The time required for the fish to reach market size is naturally longer. The ideal situation would be for the polyculture of mullet to continue until it reached a marketable size. Sampaio (2008) showed that the mullet M. platanus withstands pond rearing during the winter period. Thus, a practical application for the polyculture of mullet with the L. vannamei shrimp would be the seasonal crop of shrimp (in summer) without the interruption of the rearing of mullets (annual crops).

The practice of polyculture using structures such as net cages or surrounding with separation of species can still lead to better shrimp performance. As shrimp reached market size within 80 days of rearing, an effort towards achieving a better species weight gain can be taken as a main objective during the summer period. One possibility would be to intensify shrimp rearing in ponds with mullets, allowing mullets to indirectly obtain their food through the food chain.

\section{Conclusions}

Polyculture of shrimp and mullet reared together in earthen ponds negatively affects shrimp production and favors the production of mullets.

\section{References}

CANDIDO, A.S.; MELO JÚNIOR, A.P.; SANTOS, C.H.A. et al. Policultivo do camarão marinho (Litopenaeus vannamei) com tilápia do Nilo (Oreochromis niloticus). Arquivos de Ciências Veterinárias e Zoologia da UNIPAR, v.9, n.1, p.9-14, 2006.

CARVALHO, C.V.A. Exigência protéica de juvenis de mullet Mugil platanus. 2008. 49f. Dissertação (Mestrado em Aquicultura) Universidade Federal do Rio Grande, Rio Grande, RS.

CÓRDOBA, L.R.M.; MESSINA, E.P. Biotic communities and feeding habits of Litopenaeus vannamei (Boone 1931) and Litopenaeus stylirostris (Stimpson 1974) in monoculture and polyculture. semi-intensive ponds. Aquaculture Research, v.36, p.1075-1084, 2005.
DANAHER, J.J.; TIDWELL, J.H., COULE, S.D. et al. Effects of two densities of caged monosex nile tilapia, Oreochromis niloticus, on water quality, phytoplankton populations, and production when polycultured with Macrobrachium rosenbergii in temperate ponds. Journal of the World Aquaculture Society, v.38, n.3, p.367-382, 2007.

FONSECA NETO, J.C.; SPACH, H.L. Sobrevivência de juvenis de Mugil platanus Gunther, 1880 (Pisces, Mugilidae) em diferentes salinidades. Boletim do Instituto de Pesca, v.25, p.13-17, 1998/ 1999.

FOOD AND AGRICULTURE ORGANIZATION OF UNITED NATIONS - FAO. 2010. SOFIA - The State of World Fisheries and Aquaculture. Available at: <ftp://ftp.fao.org/docrep/fao/011/ i0250e/i0250e.pdf $>$ Accessed on: Sept. 1, 2011.

GODINHO, H.M. Mullet. In: BALDISSEROTO, B.; GOMES, L.C. (Org). Espécies nativas para piscicultura no Brasil. Santa Maria: UFSM, 2005. p.433-441.

HENNE, J.P.; ROMERO, M.M.; CARMICHAEL, G.J. Polyculture of endangered bonytails and razorback suckers in recirculated water. North American Journal of Aquaculture, v.69, n.4, p.288-394, 2007.

HOUSSAIN, M.A.; ISLAM, M.S. Stocking density of Macrobrachium rosenbergii in carp polyculture. Aquaculture Research, v.37, p.994-1000, 2006.

JANA, T.K.; BANERJEE, R.D.; JANA, B.B. Responses of some biogeochemical cycling bacteria and their activities to management protocols under polyculture with Indian major carps and freshwater giant prawn. Aquaculture, v.264, p.184-196, 2007.

JORY, D.R. Manejo integral del alimento de Camarón, de estanques de producción camaroneros, y principios de bioseguridad. Monterrey Nuevo León, México, 2001. 76p. (Curso lance en acuacultura).

LIN, Y.C.; CHEN, J.C. Acute toxicity of nitrite on Litopenaeus vannamei (Boone) juveniles at different salinity levels. Aquaculture, v.224, p.193-201, 2003.

MENEZES, N.A.; FIGUEIREDO, J.L. Manual de peixes marinhos do Sudeste do Brasil. V. Teleostei (4). São Paulo: Museu de Zoologia, Universidade de São Paulo, 1985. p.19-24.

MUANGKEOW, B.; IKEJIMA, K.; POWTONGSOOK, S. et al. Effects of white shrimp, Litopenaeus vannamei (Boone), and Nile tilapia, Oreochromis niloticus L., stocking density on growth, nutrient conversion rate and economic return in integrated closed recirculation system. Aquaculture, v.269, n.1-4, p.363-376, 2007.

NAYLOR, R.L.; GOLDBURG, R.J.; PRIMAVERA, J.H. et al. Effects of aquaculture on the world fish supplies. Nature, v.405, p.1017-1024, 2000

OLIVEIRA, I.R.; SOARES, L.S.H. Alimentação da mullet Mugil platanus Gunther, 1880 (pisces: mugilidae), da região estuarinolagunar de Cananéia, São Paulo, Brasil. Boletim do Instituto de Pesca, v.23, p.95-104, 1996.

PARSONS, G.J.; SHUMWAY, S.E.; KUENSTNER, S. et al. Polyculture of sea scallops (Placopecten magellanicus) suspended from salmon cages. Aquaculture International, v.10, n.1, p.65-77, 2002.

PHAN-VAN, M. ; ROUSSEAU, D. ; DE PAUW, N. Effects of fish bioturbation on the vertical distribution of water temperature and dissolved oxygen in a fish culture-integrated waste stabilization pond system. Aquaculture, v.281, p.28-33, 2008.

POERSCH, L.H.; SANTOS, M.H.S.; MIRANDA FILHO, K. et al. Efeito agudo do nitrato sobre alevinos de mullet. Boletim do Instituto de Pesca, v.33, n.2, p.247-252, 2007.

RAHMAN, M.M.; NAGELKERKE, L.A.J.; VERDEGEM, M.C.J. et al. Relationships among water quality, food resources, fish diet and fish growth in polyculture ponds: A multivariate approach. Aquaculture, v.275, p.108-115, 2008.

RITVO, G.; SAMOCHA, T.M.; LAWRENCE, A.L. et al. Growth of Penaeus vannamei on soils from various Texas shrimp farms, under laboratory conditions. Aquaculture, v.163, p.101-110, 1998.

RODRIGUES, J. Plataforma tecnológica do camarão marinho. Brasília: ABCC, CNPq e MAPA, 2001. 276p. 
SAMPAIO, J.A.O. Desempenho de linguados Paralichthys orbignyanus em policultivo com mullets Mugil platanus em viveiros de solo, no período de outono e inverno. 2008. 33f. Dissertação (Mestrado em Aquicultura) - Universidade Federal do Rio Grande, Rio Grande, RS.

SAMPAIO, L.A.; FERREIRA, A.H.; TESSER, M.B. Effect of stocking density on laboratory rearing of mullet fingerlings, Mugil platanus (Günther, 1880). Acta Scientiarum, v.23, n.2, p.471-475, 2001.

SCORVO-FILHO, J.D.; AYROSA, L.M.S.; NOVATO, P.F.C. et al. Efeito da densidade de estocagem sobre o crescimento da mullet listrada (Mugil platanus) criada em mono e policultivo com carpa comum (Cyprinus arpio) na região do Vale do Ribeira, SP. Boletim do Instituto de Pesca, v.22, n.2, p.85-93, 1995.

SILVA, L.B.; BARCELLOS, L.J.G.; QUEVEDO, R.M. et al. Alternative species for traditional carp polyculture in southern South America: Initial growing period. Aquaculture, v.255, p.417-428, 2006

TIAN, X.; LI, D.; DONG, S. et al. An experimental study on closedpolyculture of penaeid shrimp with tilapia and constricted tagelus. Aquaculture, v.202, p.57-71, 2001.

UDDIN, S.; AZIM, M.E.; WAHAB, A. et al. The potential of mixed culture of genetically improved farmed tilapia (Oreochromis niloticus) and freshwater giant prawn (Macrobrachium rosenbergii) in periphyton-based systems. Aquaculture Research, v.37, p.241-247, 2006.

UDDIN, M.S.; RAHMAN, S.M.S.; AZIM, M.E. et al. Effects of stocking density on production and economics of Nile tilapia (Oreochromis niloticus) and freshwater prawn (Macrobrachium rosenbergii) polyculture in periphyton-based systems. Aquaculture Research, v.38, p.1759-1769, 2007.

VALENTI, W.C. Aquicultura sustentável. In: CONGRESSO DE ZOOTECNIA, 12., Vila Real, Portugal, 2002. Anais... Vila Real: Associação Portuguesa dos Engenheiros Zootécnicos, 2002. p.111-118.

VIEIRA, P.V.; SCALABRIN, C. Migração reprodutiva da "mullet" (Mugil platanus Günther, 1980) no Sul do Brasil. Atlântica, v.13, n.1, p.131-141, 1991.

VINATEA, L.A.A. Aquicultura e desenvolvimento sustentável: subsídios para a formulação de políticas de desenvolvimento da aquicultura brasileira. Florianópolis: Ed. da UFSC, 1999. 310p.

WANG, J.; LI, D.; DONG, S. et al. Experimental studies on polyculture in closed shrimp ponds I. Intensive polyculture of Chinese shrimp (Penaeus chinensis) with tilapia hybrids. Aquaculture, v.163, n.1-2, p.11-27, 1998 